\title{
APLIKASI PENGENALAN UCAPAN SEBAGAI PENGENDALI AC DENGAN EKSTRAKSI CIRI MEL-FREQUENCY CEPSTRUM COEFFICIENTS (MFCC) DAN JARINGAN SYARAF TIRUAN (JST) PROPAGASI BALIK
}

\author{
Yulia Fitri, Sri Fitria Retnawaty, Nurul Zecha \\ Program Studi Fisika, Universitas Muhammadiyah Riau \\ e-mail:yuliafitri@umri.ac.id
}

\begin{abstract}
ABSTRAK
Perkembangan teknologi dalam bidang Pengolahan Sinyal Digital (Digital Signal Processing) telah membawa dampak positif dalam kehidupan manusia. Pengenalan sinyal digital dapat dikembangkan keberbagai aplikasi yang dapat mempermudah kehidupan manusia. Salah satu perkembangannya adalah dibidang pengenalan suara. Dalam penelitian ini dibuat salah suatu sistem pengendali AC. Pengenalan suara meliputi 4 kata yaitu, "Hidup" "Dingin" "Sedang" dan "Mati" dengan pengucapan pola benar dan pengucapan pola salah. Untuk pengenalan ini meliputi proses digitalisasi kemudian ekstraksi ciri menggunakan metode MFCC hasil dari proses MFCC berupa koefisien, koefisien ini yang dijadikan sebagai input pada Jaringan Saraf Tiruan (JST) Propagasi Balik untuk proses pengenalan. Jumlah responden berjumlah 16 orang terbagi atas 2 kelompok, dimana kelompok responden pertama data yang digunakan diuji dimana data dilatih terlebih dan kelompok responden kedua data yang digunakan diuji tanpa melalui proses latih. Hasil uji responden kelompok pertama dengan pengucapan pola benar mencapai tingkat keberhasilan rata-rata 83\%, untuk pola yang salah mencapai $90 \%$. Sedangkan untuk kelompok kedua dengan pengucapan pola benar sistem mampu mengenali $77 \%$, dan untuk pengucapan dengan pola salah sistem mampu mengenali $72 \%$.
\end{abstract}

Kata Kunci : DSP, Pengenalan Suara, MFCC, JST Propagasi Balik

\section{PENDAHULUAN}

Salah satu disiplin ilmu dalam pengolahan sinyal digital yang memberikan dampak yang cukup besar ialah dalam bidang pengolahan suara. Teknologi pengenalan suara saat ini mengalami perkembangan yang cukup pesat. Pengenalan suara digital dapat dikembangkan berbagai aplikasi yang dapat mempermudah kehidupan manusia. Air Conditioner (AC) yang merupakan sebuah alat yang mampu, mengkondisikan udara. Teknologi AC adalah teknologi terbaik dalam kategori pendingin udara dimana suhunya bisa diatur dengan bebas sesuai dengan kebutuhan, udara AC juga dapat memasuki seluruh ruangan yang ada dalam ruangan tersebut. Pada umumnya AC dikendalikan oleh remot. Ketersediaan remot yang hanya satu membuat tidak semua orang dapat mengendalikan AC dengan mudah. Oleh karena itu dibuat suatu sistem pengenalan ucapan sebagai sistem pengendali $\mathrm{AC}$ sebagai pengganti penggunaan remot. Penelitian yang telah dilakukan sebelumnya oleh Manurung (2010) Perancangan Perangkat Lunak Simulasi Air Conditioner (AC) Dengan Menggunakan Algoritma Logika Fuzzy. Pada penelitian ini dibuat sebuah aplikasi pengenalan ucapan sebagai pengendali AC menggunakan MFCC dan JST Propagasi Balik.

Pemilihan MFCC sebagai ekstraksi ciri karena MFCC memiliki beberapa kelebihan yaitu mampu menangkap informasi penting dalam sinyal suara, menghasilkan data seminimal mungkin tanpa menghilangkan informasi-informasi yang ada, dan mereplikasikan organ pendengaran manusia dalam melalukan persepsi terhadap sinyal suara (Andiana, 2013). Sedangkan JST mampu menyelesaikan persoalan yang rumit atau bahkan tidak mungkin jika diselesaikan menggunakan komputasi konvensiolan. Selain itu, JST mampu menyesuaikan diri belajar dan mengelola data (Agustini, 2006). Salah satu jenis JST yang mampu bekerja dengan baik adalah JST dengan metode propagasi balik. 
Meskipun JST propagasi balik membutuhkan waktu pembelajaran yang lama namun bila pembelajaran telah selesai, JST akan mengenali pola dengan cepat (Chaidir, 2010).

\section{METODOLOGI PENELITIAN}

Diagram alir penelitian dari pembuatan program aplikasi ucapan untuk pengendali AC dapat dilihat pada Gambar 2.1

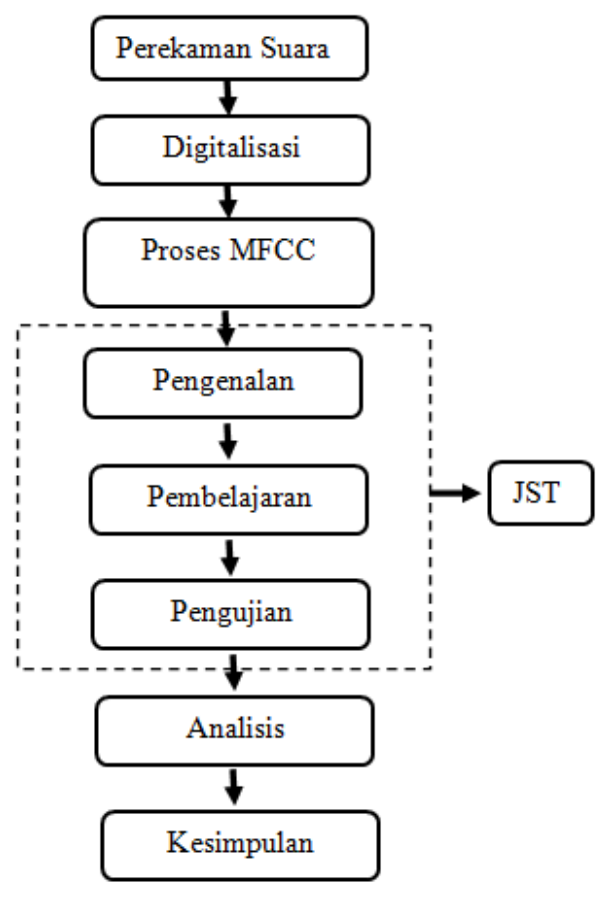

Gambar 2.1. Diagram Alir Penelitian

\section{Perekaman Suara Ucapan}

Perekaman ucapan digunakan sebagai masukan perintah pada program. Perekaman ucapan yang digunakan untuk penelitian ini menggunakan Software praat. Ucapan yang direkam adalah ucapan "Hidup" "Dingin" "Sedang" dan " Mati" dengan pengucapan pola benar dan pengucapan polsa salah. Hasil perekaman kemudian disimpan dalam bentuk format.wav.

Perekaman ucapan dilakukan oleh 14 responden dan dibagi atas 2 kelompok. Responden kelompok pertama sebagai data pembelajaran dan responden kelompok kedua sebagai data uji. Jumlah responden pada kelompok pertama adalah 10 responden yang terdiri dari 5 laki-laki dan 5 perempuan. Jumlah responden pada kelompok kedua adalah 4 responden terdiri dari 3 laki-laki dan 3 perempuan. Dengan rentang umur untuk semua responden adalah 18-35 tahun.

Pada responden kelompok pertama setiap orang merekam suara sebanyak 10 pengulangan untuk setiap pengucapan pola benar maupun pengucapan pola salah. Dari 10 kali pengulangan ini 7 diantaranya digunakan sebagai data pembelajaran dan 3 pengulangan selanjutnya digunakan sebagai data uji dari suara yang telah dipelajari sebelumnya. Sehingga untuk kata "Hidup" setiap responden akan melakukan 20 kali proses perekaman suara. Maka jumlah data yang dihasilkan oleh setiap responden adalah 80 data suara. Sehingga total data suara dari seluruh responden adalah 800 data suara yang terdiri dari 560 data untuk pembelajaran dan 240 data uji dari suara yang telah dipelajari.

Pada responden kelompok kedua yang berjumlah 6 orang responden hanya melakukan perekaman suara sebanyak 3 kali untuk ucapan yang benar maupun yang salah. Sehingga untuk kata "Hidup" responden melakukan 6 kali proses pengulangan perekaman, begitu untuk kata seterusnya. Maka jumlah data suara yang dihasilkan unruk setiap responden adalah 24 data suara. Sehingga total data suara yang dihasilkan dari seluruh responden kelompok kedua adalah 144 data. Seluruh data suara ini akan langsung diuji pada sistem tanpa proses pembelajaran terlebih dahulu. Hasil dari proses perekaman suara ini akan dilanjutkan proses Digitalisasi dan MFCC menggunakan software Praat. Hasil keluaran dari proses MFCC digunakan sebagai masukan (input) pada proses JST.

\section{Sistem Pengenalan JST Propagasi Balik}

Setelah melewati proses ekstraksi ciri menggunakan MFCC maka suara akan menghasilkan parameter berupa koefisien. Koefisien inilah yang akan menjadi masukan (input) pada proses selanjutnya yaitu JST Propagasi Balik. Pada JST Propagasi Balik ini dilakukan 3 (tiga) proses yaitu pembelajaran, pengenalan dan pengujian. Proses ini 
dilakukan menggunakan Software Matlab. Seluruh koefisien yang dihasilkan pada proses MFCC akan digunakan JST untuk membentuk sebuah referensi, referensi ini didapatkan ketika sistem JST melakukan pembelajaran. Setelah proses pembelajaran selesai maka sistem JST akan melakukan pengujian dengan mencocokkan pola masukkan (input) dari setiap ucapan sehingga akan memeberikan hasil berupa besarnya skor kesesuaian antara input dengan pola referensi tersebut.

\section{HASIL DAN PEMBAHASAN}

Pengujian terhadap sistem pengenalan ucapan yanng dibuat dalam penelitian ini menggunakan JST Propagasi Balik (Back Forward). Sistem JST menggunakan sistem JST multi layer network yang terdiri dari satu lapisan masukan, satu lapisan tersembunyi dan satu lapisan keluaran. Multi layer yang digunakan adalah 100, 200, 1. Setiap kata yang akan menjadi masukkan akan diterima oleh seluruh lapisan (layer) pertama kemudian dari lapisan pertama ini data akan diproses kembali pada layer kedua. Selanjutnya dari lapisan kedua data akan diproses kembali pada lapisan terakhir.

Berdasarkan pola pengenalan ucapan, program ini menggunakan 2 parameter, yaitu pola suara yang dianggap benar dilihat dari segi benar atau tidaknya dalam mengeja huruf. Sehingga hasil dari keluaran yang diharapkan akan terbagi menjadi dua yaitu suara dengan pola yang benar dan suara dengan pola yang dianggap salah. Dari seluruh proses ini keluaran yang dihasilkan berupa nilai 0 dan 1 . Dimana nilai 1 untuk hasil keluaran ucapan dengan pola benar dan nilai 0 untuk keluaran dengan pola salah. Penentuan nilai target ini dilakukan agar keluaran dari pola suara yang dilatih maupun diuji akan sesuai dengan target yang telah ditentukan sehingga jaringan pada akhirnya dapat memutuskan suatu pola suara benar atau salah.

\section{Pengujian Menggunaan Data Latih}

Proses pertama yang dilakukan dalam pengujian adalah pengujian menggunakan data latih. Pengujian menggunakan data latih merupakan pengujian yang dilakukan terhadap data yang terlebih dahulu dilakukan proses pembelajaran.

Dimana setiap kata benar (B) pada Kelompok pertama (K-1) responden pertama (R1) untuk pengucapan kata hidup $(\mathrm{H})$ pada pengulangan pertama hingga pengulangan ke tujuh (BR1H1-BR1H7) akan dijadikan sebagai data pembelajaran. Sedangkan pada pengulangan ke 8-10 (BR1H8- BR1H10) akan dijadikan sebagai data uji sebagai hasil dari pembelajaran. Pengujian ini juga dilakukan pada semua kata dengan pola salah (S). Data pengucapan kata dengan pola yang salah pada kelompok responden pertama untuk pengulangan pertama hingga ke tujuh (SR1H1-SR1H7) akan dijadikan pembelajaran. Data selanjutnya yaitu data ke delapan hingga kesepuluh (SR1H8- SR1H10) akan dijadikan sebagai data uji.

Dari hasil pengujian sistem untuk kata hidup dengan pengucapan pola yang benar menggunakan data latih, sebesar $83 \%$ sistem mampu mengenali dengan tingkat keberhasilan $100 \%$. Hasil ini menunjukan bahwa sistem ini mampu mengenali ucapan dengan baik, ini ditunjukan dari hasil yang mendekati nilai target 1 . Hasil dengan keberhasilan yang sama juga pada pola pengucapan kata hidup yang salah dengan nilai target nol (0) sistem dapat mengenali ucapan dengan keberhasilan 90\%. Hasil ini menunjukan bahwa sistem mampu mengenali ucapan dengan pola benar dan pengucapan dengan pola salah dengan baik.

\section{Pengujian Tanpa Data Latih}

Pengujian kedua merupakan pengujian tanpa data latih. Pengujian kedua digunakan data dari responden kelompok kedua dimana pengujian yang dilakukan terhadap data yang direkam dan langsung dilakukan proses uji tanpa dilakukan pembelajaran terlebih dahulu. Hasil pengujian tanpa data latih untuk kata hidup dengan pola yang benar sebesar $77 \%$ sistem mampu mengenali dengan tingkat keberhasilan 100\%. Sedangkan 23\% lainnya sistem mampu mengenali diatas nilai $90 \%$. 
Tingkat keberhasilan pada kata yang sama untuk pola salah sistem dapat mengenali data dengan keberhasian 72\%. Hasil pengujian menunjukan bahwa sistem tanpa data latih dapat mengenali dengan baik.

\section{KESIMPULAN}

Dari hasil uji coba sistem yang dilakukan sistem dapat disimpulkan bahwa :

1. Sistem mampu mengenali suara dengan ucapan Hidup, Dingin, Sedang dan Mati baik dari suara yang benar maupun yang salah.

2. Hasil pengujian data menggunakan data latih untuk pengucapan pola benar sistem mampu mengenali ucapan sebesar $83 \%$, begitupun untuk pengucapan pola yang salah sistem mampu mengenali dengan tingkat keberhasilan $90 \%$.

3. Hasil pengujian tanpa data latih untuk kata hidup dengan pola benar sistem mampu mengenali sebesar $77 \%$, dan untuk pengucapan pola salah sistem dapat mengenali data dengan keberhasilan $72 \%$.

4. Berdasarkan semua hasil pengujian maka program dengan metode ektaksi ciri MFCC dan JST Propagasi Balik dapat diaplikasikan untuk sistem pengenalan suara untuk menghidupkan AC.

\section{DAFTAR PUSTAKA}

Agustini, Ketut. 2006. Perbandingan Metode Tranformasi Wavelet sebagai Praproses pada Sistem Identifikasi Pembicara. Bogor. Sekolah Pasca Sarjana Institut Pertanian Bogor.

Andriana, Anna Dara. 2013. Perangkat Lunak untuk Membuka Aplikasi pada Komputer dengan Perintah Suara menggunakan Metode Mel-Frequency Cepstrum Coefficients. Jurnal Ilmiah Komputer dan Info. Vol. 2. No. 1, Maret 201. ISSN: 2089.9033

Chaedir, zul. 2010. Pengenalan Huruf dan Angka Pada Citra Bitmap Dengan Jaringan Syaraf Tiruan Metode Propagasi Balik. Yogyakarta. Jurusan Teknik Informatika. Sekolah Tinggi Menajeman Informatika Dan Komputer Amikom.

Manurung, Fernando Elfriedo. 2013. Perancangan Perangkat Lunak Simulasi Air Conditioner (AC) Dengan Menggunakan Algoritma Logika Fuzzy. Pelita Informatika Budi Darma, Volume : V, Nomer 1, Nov 2013. ISSN :2301-9425 